\title{
CLIMATE CHANGES AND ADAPTATION OF SOME MARINE ORGANISMS - PERSIAN GULF STUDY CASE
}

\author{
Zahra KHOSHNOOD *, Mehdi GHOBEITIHASAB * and Ali HAJINAJAF **
}

* Department of Biology, College of Science, Dezful Branch, Islamic Azad University, Dezful, Iran, P. O. Box 313, IR-64618-57518, ZKhoshnood@gmail.com, Ghobeiti@yahoo.com.

** Department of Experimental Sciences, Faculty of Science, Dezful Branch, Islamic Azad University, University Boulevard, Ahvaz, Iran, IR-61349-37333, Ali_bamaram1@yahoo.com

KEYWORDS: global warming, adaptation, effects, Persian Gulf.

DOI: 10.1515/trser-2015-0069

\section{ABSTRACT}

Data records since from 2008 to 2012 show the occurrence of the coral reef bleaching, an increase in population of jellyfish and a decreasing presence of some migratory marine mammals in the Persian Gulf has increased. Results of our biometric methods on jellyfish of the Persian Gulf (Aurelia aurata), show a significant increase in size during the last four years $(\mathrm{p}<0.05)$. Our studies in the area showed that in the sampling areas in close proximity to superhot wastewater of industries cooled in terrestrial pools and then emptied into the sea, the abundance of the Aurelia aurata was significantly lower than in regions where superhot water was directly emptied into the seawater. This paper will review the effects of global warming, especially in the Persian Gulf.

ZUSAMENNFASSUNG: Klimaveränderungen und die diesbezügliche Anpassung einiger Meeresorganismen - Fallstudie im Persischen Golf.

Datenaufzeichnungen von 2008-2012 zeigten, dass das Auftreten der Korallenriffbleiche, die wachsenden Populationen gallertartiger Fische und die Verringerung des Vorkommens einiger mariner, wandernder Säugetiere im Persischen Golf größere Ausmaße angenommen hat. Ergebnisse unserer biometrischen Methoden angewandt auf den gallertartigen Fisch Aurelia aurata des Persischen Golfs belegen ein signifikantes Größenwachstum während der letzten vier Jahre $(\mathrm{p}<0.05)$. Unsere Untersuchungen zeigten, dass in den Probenahmegebieten, in denen sehr heißes Abwasser aus der Industrie in terrestrischen Becken gekühlt und dann in das Meer gelehrt wurden, die Abundanz von Aurelia aurata signifikant niedriger war als in den Gebieten, in denen sehr heißes Water direkt ins Meer eingeleitet wurde. In vorliegender Arbeit werden die Auswirkungen der globalen Erwärmung, insbesondere im Persischen Golf im Überblick dargestellt.

REZUMAT: Schimbările climatice și adaptarea unor organisme marine la acestea studiu de caz Golful Persic.

Datele provenite din perioada 2008-2012 dezvăluie o manifestare crescută a fenomenului de albire a recifului de corali, creșterea populației de meduze și scăderea prezenței unora dintre mamiferele migratoare din Golful Persic. Rezultatele măsurătorilor biometrice asupra meduzelor din Golful Persic (Aurelia aurata) au arătat o creștere semnificativă în mărime în ultimii patru ani $(\mathrm{p}<0.05)$. Studiile noastre au arătat că zonele unde a fost deversată apa fierbinte și poluată provenită de la diferite industrii în bazine de răcire și apoi în mare, sunt prezente un număr semnificativ mai mic de indivizi din specia Aurelia aurata decât zonele unde această apă fierbinte era deversată direct în mare. În lucrare abordăm aspecte legate de efectele încălzirii globale asupra cenozelor din în Golful Persic. 


\section{INTRODUCTION}

Changing the environmental conditions in aquatic ecosystems is a major concern of many research projects all over the world. Climate change due to natural and anthropogenic activities are amongst the major reasons of such changes (Halpern et al., 2008).

IPCC reports that the atmosphere temperature has been rise during this century due to increasing the greenhouse gases (IPCC, 2007).

Different studies showed that changes in atmosphere temperature could lead to different changes in oceans and aquatic ecosystems in all aspects of biological, chemical or physical properties (Ji et al., 2007).

It has been shown that such changes could be different in case of different geographical sites; for example increasing in ocean temperature in some locations and decreasing the ocean temperature in some other ones (Scranton et al., 1987; Freeland, 1990; Bethoux et al., 1998; Read and Gould, 1992).

It has been previously declared that any alterations in abiotic aspects of marine environments (such as temperature, salinity, $\mathrm{pH}$, currents, upwelling or down welling, UV radiation, etc.) could affects the biotic properties of that ecosystem and made some huge changes in food web and aquatic organisms life (IPCC, 1996, 2007; Ji et al., 2007).

In this paper we will review some effects of global warming, especially in the Persian Gulf and the activities for adaptation to its effects.

\section{MATERIAL AND METHODS}

The six sampling area on the northern coastline of the Persian Gulf (Fig. 1).

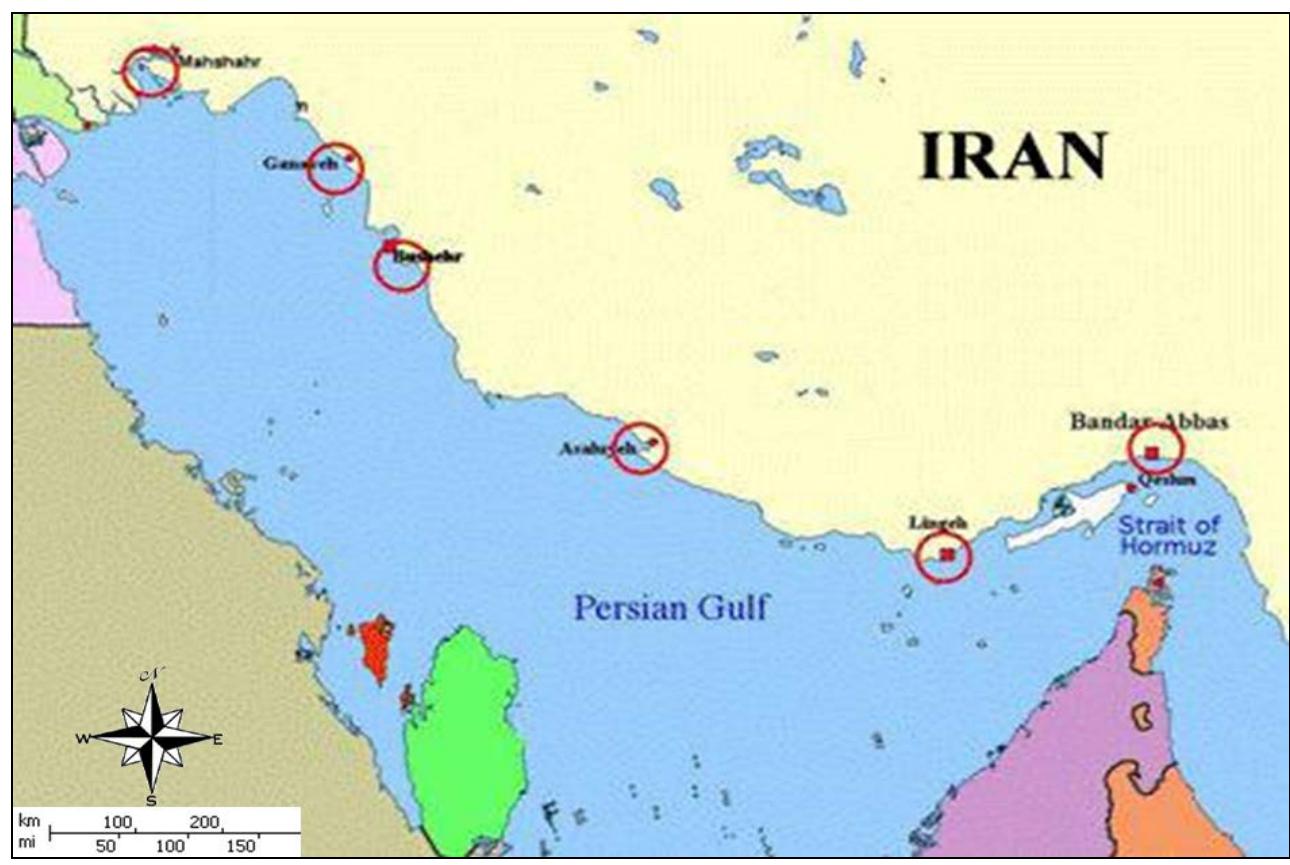

Figure 1: Sampling sites areas in Iranian coastal waters of the Persian Gulf.

Six sampling regions were selected as follow: Bushehr, Asaluyeh, Lengeh, Genaveh, Mahshahr, and Bandar Abbass. All sampling were performed during spring 2008 to winter 2012. Jellyfish species, sampled by zooplankton net (one m diameter, $500 \mu \mathrm{m}$ mesh size, fitted with a flow meter), and samples of the jellyfish were immediately transferred to the laboratory after the collection for biometric measurements. 


\section{RESULTS AND DISCUSSION}

\section{Biometry, Abundance and Morphological Features}

The focus of jellyfish sampling was on the species: Aurelia aurita, and the biggest diameter of the top of the bell was measured using biometry scale, the result of the mean body size of the samples in six sampling areas shown in figure 2. Results showed that the samples at the Asaluyeh sampling area were significantly bigger in size than the other sampling sites. Asaluyeh sampling site was the most significant site for the petrochemical industries.

Also results of the abundance of the jellyfish at the six sampling sites is shown in figure 3, results showed that abundance at Asaluyeh sampling site was significantly higher than the other sampling areas.

The jellyfish was translucent, and can be recognized by its four horseshoe-shaped gonads, easily seen through the top of the bell, and short tentacles beneath the bell (Fig. 4).

\section{Coral Reef Bleaching}

The coral reef bleaching is repeatedly reported by the marine environment protection agency of the Iran during past the decade. In the Persian Gulf the greatest abundance of coral reefs is in the northern part of the sea along the Iranian coastline and around the Iranian islands. Bleaching is reported in different species of corals but especially at the Kish Island coastal waters (Fig. 5).

There are many scenarios that show the resulting effects of the increase in Earth's temperature, and there are also uncertainties about some of them, but the fact is that many of these scenarios were experienced in natural and laboratory conditions and their results were significant.

Global warming and the increase in Earth's temperature can affect the marine ecosystem, directly and indirectly (Kosnik, 2008). As a direct effect, increasing the temperature of water in marginal seas can put the life of temperature-sensitive species (stenotherm) in danger, like salmon. Increasing water temperature can affect feeding, spawning, larval growth and many other physiological processes, and cause mortality. Extinction or elimination of some species from an ecosystem can affect the whole ecosystem through food chain; this can be counted as an indirect effect of global warming on marine life (Beardall and Raven, 2004).

Some other important effects of global warming on marine ecosystems are: changes in the ocean currents (because of misbalancing in heat conditions) that can have serious effects on both the ocean and terrestrial ecosystems (because oceanic currents affected the distribution of marine organisms, and also specific temperature and availability of nutrients in every region were mainly dependent to oceanic currents pattern).

Melting of polar caps, that means destroying of some special species habitat like the polar bears, melting of glaciers and increasing in freshwater input of the oceans, makes oceans less saline, and a decreasing in salinity can led to extinction of salinity-sensitive species (stenohaline) like valuable species of corals, also melting of glaciers increases the turbidity in near shore waters (because of their high load of sediments) and affect the photosynthesis in marine plants, decreases the productivity, and causes mortality in fishes, crustaceans, and other habitants mainly larvae (Hinga, 2002). 


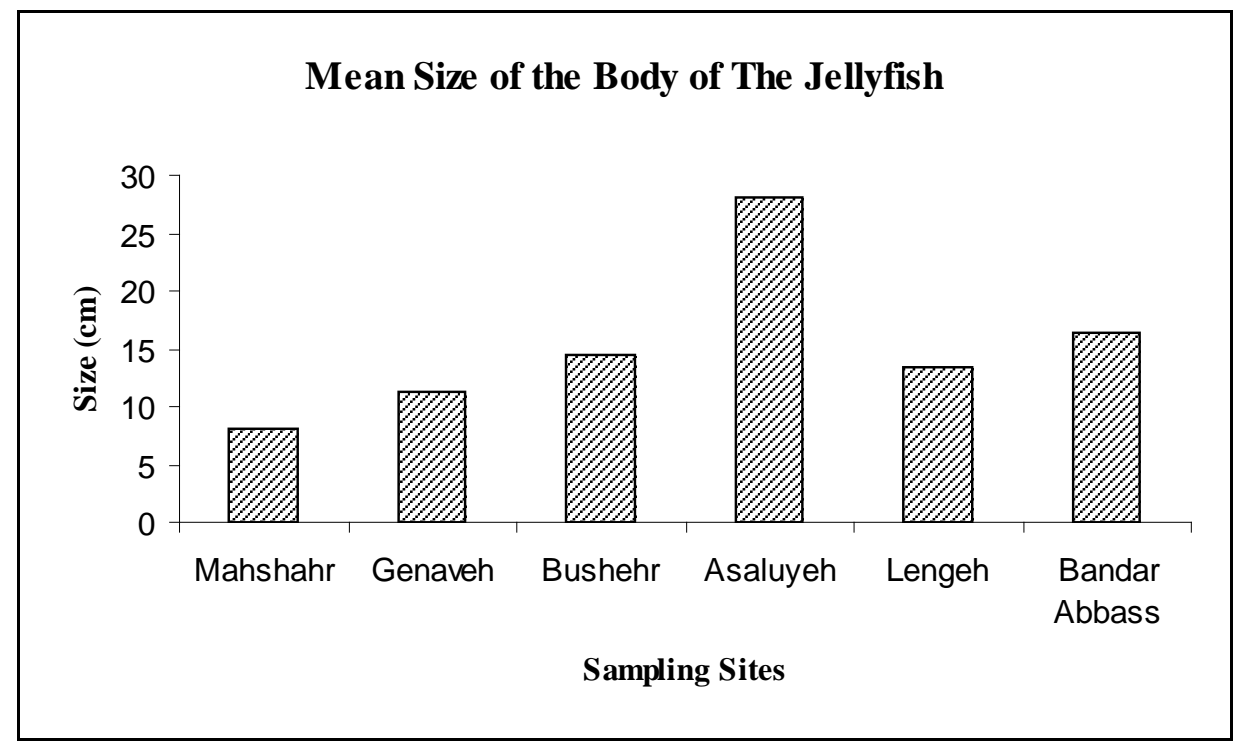

Figure 2: The mean body size of the Aurelia aurita at the six sampling sites along northern part of the Persian Gulf.

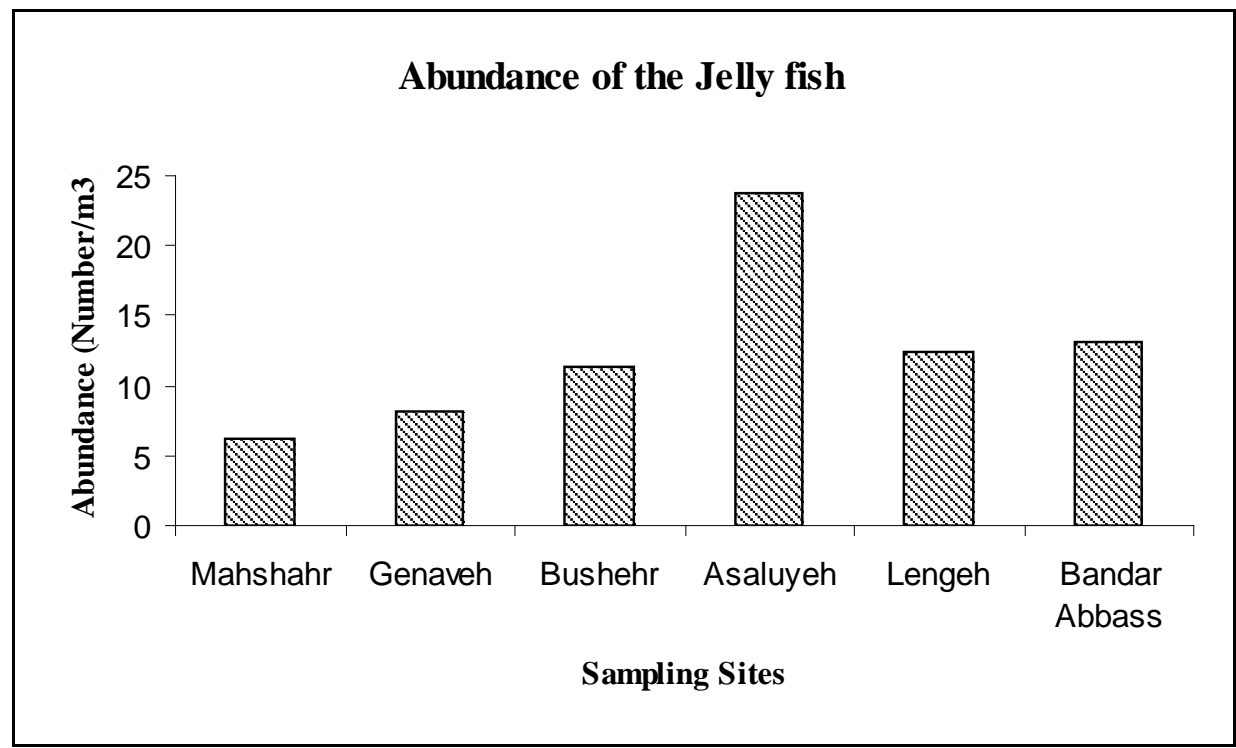

Figure 3: Abundance of the Aurelia aurita in six sampling sites along northern part of the Persian Gulf (mean values).

Increasing in sea level because of melting ice and heat-made water volume increase, will destroy the coastal habitats and their inhabitant species; increases in atmospheric $\mathrm{CO}_{2}$ results in increases of the $\mathrm{CO}_{2}$ concentration in the ocean, this increase causes the seas to be more acidic which can affect the life of shelled organisms (like corals, molluscs, foraminiferans, cocolithophores and others) because of changes in $\mathrm{CaCO}_{3}$ availability, this acidification can also affect marine plants and physiological processes of marine organisms directly; and finally drought made by the increase in Earth temperature and changes in climate, destroying some of the lakes and habitats all over the world followed by extinction of its inhabitants (Florides and Christodoulides, 2008). 


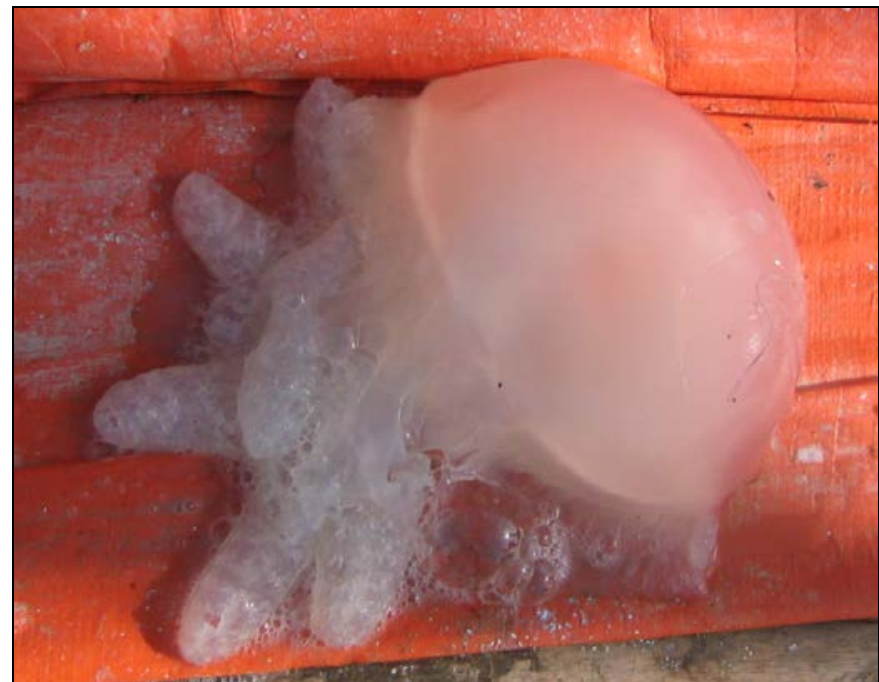

Figure 4: Aurelia aurita caught by the zooplankton net at the boat at the Persian Gulf.

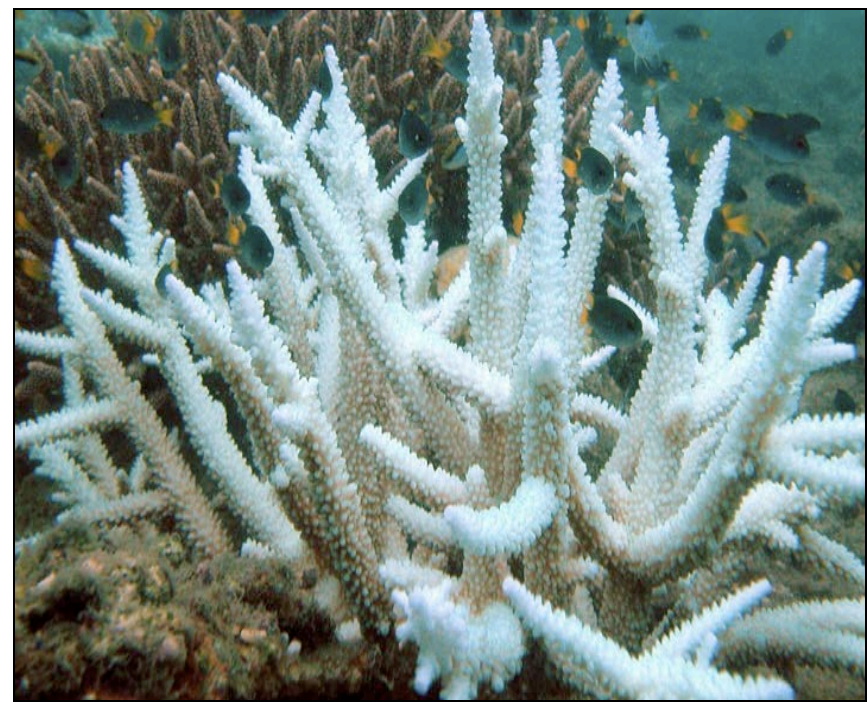

Figure 5: Coral reef bleaching in the Persian Gulf.

\section{CONCLUSIONS}

Global warming is a very complicated phenomenon and its effects on different aspects of life on the earth are still unclear. Today many investigations predict these effects and the possible ways of prevention of the increases in global warming. It is clear that for controlling a global phenomenon we need a global will. For example although a high amount of $\mathrm{CO}_{2}$ is released to the atmosphere by developed countries, but degradation of forests and uses of worn out machinery by developing and undeveloped countries have a great role in increasing the effects of global warming too. So for solving our global problem we need to prevent every harmful activity for the earth's ecosystem and try to improve our previous harmful activities.

We conclude that because of the Asaluyeh specific environment (petrochemical environment) the jellyfish were significantly bigger and in larger numbers which can be linked to differences in temperature between sites. 


\section{ACKNOWLEDGEMENTS}

The authors wish to thank to Mr. Afkhami and Mrs. Ehsanpour for their great help during the experimental processes.

\section{REFERENCES}

1. Beardall J. and Raven J. A., 2004 - The potential effects of global climate change in microalgal photosynthesis, growth and ecology, Phycologia, 43, 31-45.

2. Bethoux J. P., Gentili B. and Tailliez D., 1998 - Warming and fresh-water budget change in the Mediterranean since the 1940s, their possible relation to the greenhouse effect, Geophysical Research Letters, 25, 1023-1026.

3. Florides G. A. and Christodoulides P., 2008 - Global warming and carbon dioxide through sciences, Environment International, 48, 441-453.

4. Freeland H. J., 1990 - Sea surface temperatures along the coast of British Columbia: regional evidence for a warming trend, Canadian Journal of Fisheries and Aquatic Sciences, 47, 346350.

5. Halpern B. S., Walbridge S., Selkoe K. A., Kappel C. V., Micheli F., D’Agrosa C., Bruno J. F., Casey K. S., Ebert C., Fox H. E., Fujita R., Heinemann D., Lenihan H. S., Madin E. M. P., Perry M. T., Selig E. R., Spalding M., Steneck R. and Watson R., 2008 - A global map of human impact on marine ecosystems, Science, 319, 948-952.

6. Hinga K. R., 2002 - Effects of pH on coastal marine phytoplankton, Marine Ecology Progress Series, 238, 281-300.

7. IPCC, 1996 - Intergovernmental Panel on Climate Change.

8. IPCC, 2007 - Intergovernmental Panel on Climate Change.

9. Ji R., Davis C. S., Chen C. S., Townsend D. W., Mountain D. G. and Beardsley R. C., 2007 Influence of ocean freshening on shelf phytoplankton dynamics, Geophysical Research Letters, 34, L24607, doi:10.1029/2007GL032010.

10. Kosnik L., 2008 - The potential of water power in the fight against global warming in the US, Energy Policy, 36, 3252-3265.

11. Lin C., Ning X., Su J., Lin Y. and Xu B., 2005 - Environmental changes and the responses of the ecosystems of the Yellow Sea in 1976-2000, Journal of Marine Systems, 55, 223-234.

12. Read J. F. and Gould W. J., 1992 - Cooling and freshening of the subpolar North Atlantic Ocean since the 1960s, Nature, 360, 55-57.

13. Scranton M. I., Sayles F. L., Bacon M. P. and Brewer P. G., 1987 - Temporal changes in the hydrography and chemistry of the Cariaco Trench, Deep-Sea Research, 34, 945-963. 